\title{
衛星搭載全方位モニタカメラの開発*1 \\ Development of Omnidirectional Vision System for Spacecraft On-Orbit Monitoring
}

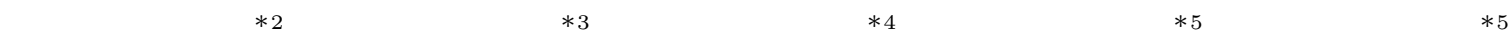 \\ Akito Takeya, Katsuhiko Yamada, Shinobu Matsuoka, Koichi IJichi and Shuji Nakamura
}

Key Words : Omnidirectional Vision, 360 Degree Image, On-Orbit Monitoring, Spacecraft

\begin{abstract}
We have developed an OmniDirectional Vision system (ODV) using two reflecting mirrors to monitor a spacecraft on orbit. Recently, a spacecraft is loaded with many deployable structures. The ODV provides a panoramic image of 360 degree surroundings in real time and is possible to monitor two or more deployable structures at the same time. Moreover, the CCD and the lens are not exposed to cosmic rays, because these are covered with metallic mirrors. Therefore, a loss of the CCD element and a blur of the lens due to the cosmic rays are not occurred easily. We have designed the ODV for the Unmanned Space Experiment Recovery System (USERS) spacecraft which was launched on September 10, 2002. The optical characteristics of the ODV has been evaluated and the results show that the ODV can acquire a sharp image. Two ODVs were adopted as monitor cameras of the USERS. From the input images of the ODVs on orbit, the deployment of the paddles and the Capillary Pumped Deployable Radiator (CPDR) and the separation of the Re-entry Module (REM) were confirmed.
\end{abstract}

\section{1. は じめに}

近年 , 衛星には, 軌道上で展開される構造物として太陽 電池パドルのみならずアンテナなど数多く搭載されている これらの展開構造物が展開中などに故障した場合 , 従来搭 載されている加速度センサや熱センサなどのセンサ情報だ けでは, 故障原因の究明に多くの時間を要していた . そこ で, これら構造物を視覚的にモニタするためのカメラの搭 載が要望されている.多くの展開構造物をモニタするため には, 弚れ光れにカメラが必要となるが, 搭載重量や電力 の制限により, 多くのカメラを搭載することは容易ではな い.よって, 複数の展開構造物を 1 台で同時にモニタする ために，全方位を視野とする視覚システムが必要となった． 全方位を常時観測するために，1枚の回転対称な曲面鏡 に映し出された全方位の映像をカメラで撮像する視覚シス テムか数多く提案されている．例えば，円錐鏡 ${ }^{1)}$, 球面鏡 ${ }^{2)}$, 双曲面鏡 ${ }^{3,4)}$, 放物面鏡5) などのシステムがあげられる .こ れらのシステムには, 非点収差と像面湾曲か生じるため, 曲 面鏡に映し出される像はボケてしまう．弚の状態て鮮明な 画像を得るためには, カメラの絞りを絞ることなどにより 被写界深度を深くする必要がある.しかし, 光量の少ない 環境下で絞ることができない場合，鮮明な画像を得ること

*1 (C) 2007 日本航空宇宙学会

平成 18 年 6 月 8 日, 26 th ISTS において発表.平成 19 年 4 月 23 日原稿受理

*2 三菱電機 (株) 先端技術総合研究所

$* 3$ 名古屋大学大学院工学研究科

$* 4$ 三菱電機 (株) 鎌倉製作所

$* 5$ (財)無人宇宙実験システム研究開発機構
は難しくなる．また，得られる画像は 1 回反射された画像 なので, 左右反転してしまうという問題も生じる .

我々は, 先に提案した主, 副 2 枚の反射鏡からなる全方位 視覚システム ${ }^{6)}$ (OmniDirectional Vision system : ODV) を応用して衛星搭載全方位モニタカメラを開発した．第 1 図に示すように，この全方位モニタカメラは反射鏡を 2 枚 用いているので, 1 枚のみ使用しているシステムと比べて 設計の自由度が高く, 非点収差や像面湾曲を補正すること が容易である。よって，絞ることなく鮮明な全方位画像を 得ることができる.また，得られる画像は 2 回反射された 画像で，左右反転することもない．

第 2 図，第 3 図に示すように，全方位モニタカメラ は次世代型無人宇宙実験システム (Unmanned Space Experiment Recovery System:USERS $)^{7)}$ に 2 台 (ODV1, 2) 搭載され，几長系を構成している．光して，太陽電池 パドルや展開ラジエター (Capillary Pumped Deployable Radiator : CPDR) の展開, リエントリモジュール (Reentry Module : REM) の分離をモニタするために使用さ れた .

USERS は財団法人無人宇宙実験システム研究開発機構 が経済産業省及び新エネルギー・産業技術総合開発機構の 委託を受け, 以下の目的で 1995 年より開発が進められた 宇宙実験システムである .

・無人宇宙実験システムの開発

・高温超電導材料の結晶成長実験

・民生技術・部品の軌道上検証

サービスモジュール (Service Module : SEM) と REM か ら構成されており，2002 年 9 月 10 日に H-IIA ロケットに 


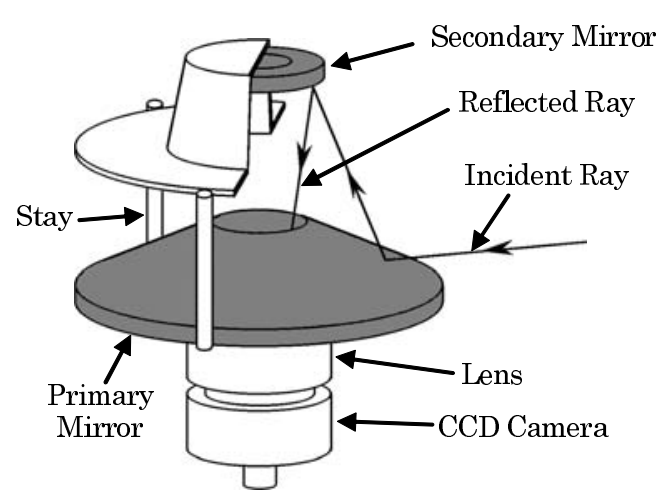

第 1 図 衛星搭載全方位モニタカメラ

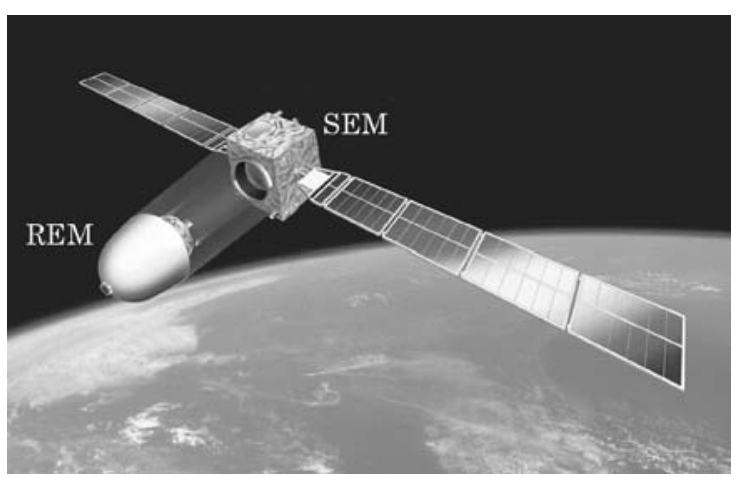

第 2 図次世代型無人宇宙実験システム (USERS) 宇宙機

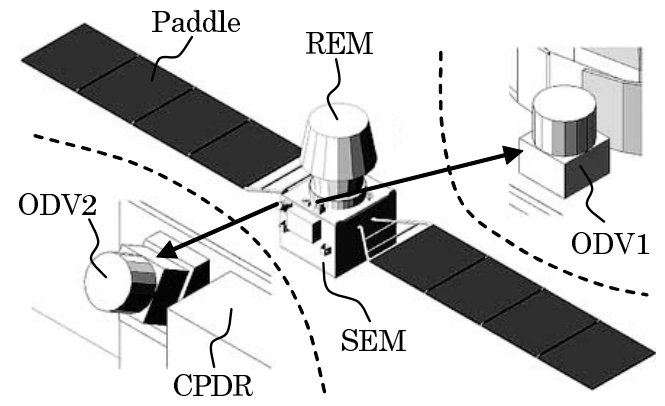

第3図 USERS の構成

より打ち上げられ，軌道高度約 $500 \mathrm{~km}$ の円軌道上で運用 された . SEM は，REMや実験装置への電力や通信サービ スを供給し，姿勢や軌道の制御を行う衛星バスシステムで ある．REM は，軌道離脱モ一タ等を搭載しているプロパ ルジョンモジュール (Propulsion Module : PM) と，実験 終了後の超電導材料を搭載し地上に帰還して回収されるリ カバリービークル (REcovery Vehicle : REV) から構成さ れている。

本論文では，まず，全方位モニタカメラの構造と特徵に ついて述べる.続いて，全方位モニタカメラの開発に関し て設計方法, 搭載位置の検証, 設計と製作, 光学系の評価 結果について述べる.最後に，軌道上での USERS におけ る撮像結果について述べる.

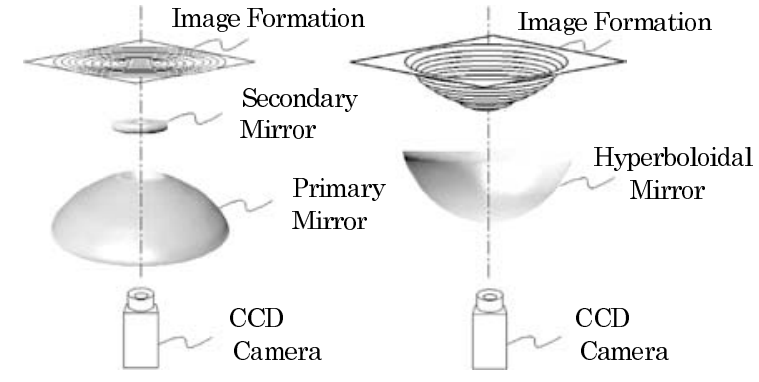

(a) 全方位モニタカメラ

(b) 従来システム

\section{2. 全方位モニタカメラの構造と特徵}

今回我々が開発した全方位モニタカメラは常時全周のパ ノラマ画像を得ることができる視覚システムである．第 1 図に示すように，この全方位モニタカメラは，対向配置さ れた 2 枚の回転対称な反射鏡，レンズ，CCD カメラから 構成されている. 全周の光景からの入射光が主鏡, 副鏡の 順に弚れ光れの鏡面で反射され，主鏡の開口部を通過して カメラのレンズに入射するように構成され，副鏡により結 ばれた像をカメラで撮像することにより全周のパノラマ像 が得られる.この視覚システムを構成している反射鏡は屈 折レンズと比べて非球面化が容易で，この特長により屈折 光学系では実現困難な種々の視野, 射影が比較的容易に実 現できる．また，CCD とレンズは金属反射鏡によりカバー されていて, 宇宙線による CCD 画素の損傷やレンズの変 色が生じにくい構造となっている。

第 4 図に我々が開発した全方位モニタカメラと従来型で ある放物面鏡視覚システムの比較図を示す．従来システム の場合，反射鏡が 1 枚構成なのて設計の自由度が低く，反射 鏡により結ばれる虚像の像面は平坦にならない，一方，全 方位モニタカメラの場合，反射鏡の 2 枚構成なので設計の 自由度が高く，副鏡により結ばれる虚像の像面を従来シス テムより平坦にすることが可能である，像面が平坦である ほど CCD カメラの焦点が合わせやすいので, 全方位モ二 タカメラのほうがより鮮明な画像を得ることが可能である.

\section{3. 全方位モニタカメラの開発}

3.1 設計方法 主鏡, 副鏡ともに回転対称であるから 断面形状を決定すれば形状が決定する.第 5 图に全方位モ ニタカメラ反射光学系の設計方法を説明するための図を示 す. 第 5 図において, 視点 $O$ を座標の原点とし, 横軸を $x$ 軸，縦軸を反射鏡の回転対称軸である $z$ 軸とする .ここで, 以下の条件を与えることにより，主鏡の断面形状が一意的 に決まる。

条件 1 主鏡への入射光の入射範囲 $\theta_{\text {min }} \sim \theta_{\text {max }}$ ， 視点 $O$ への反射光の入射範囲 $\phi_{\min } \sim \phi_{\max }$, $\theta$ と $\phi$ の関係 (射影) $\theta=g(\phi)$

条件 2 副鏡の断面形状 $f_{2}(x)$

条件 3 主鏡の内周上の点 $M_{1}$ の位置 


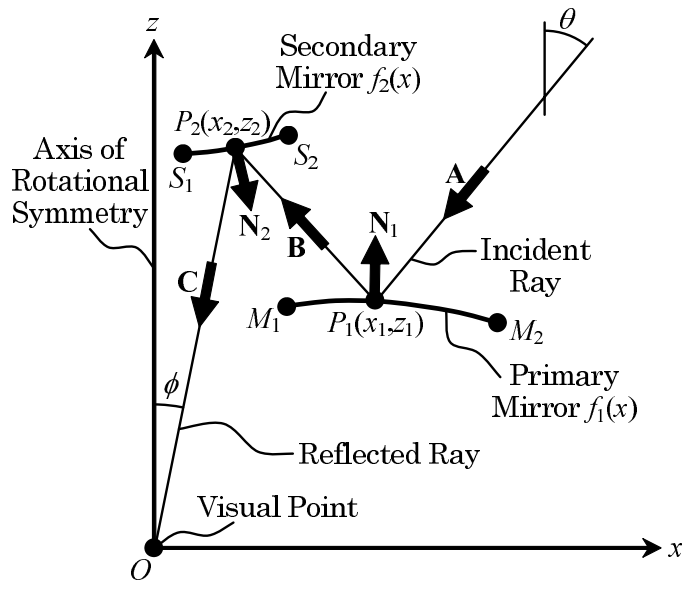

第 5 図 設計方法

上記の条件に乥って主鏡の断面形状 $f_{1}(x)$ を求める. 第 5 图で示すように, 光線が点 $P_{1}$, 点 $P_{2}$ で反射され, 視点 $O$ に入射する場合について考える.点 $P_{1}$, 点 $P_{2}$ の座標を 弚れ枈れ $\left(x_{1}, z_{1}\right),\left(x_{2}, z_{2}\right)$ とし，入射光べクトルを $\boldsymbol{A}$, 点 $P_{1}$ での反射光べクトルを $\boldsymbol{B}$, 点 $P_{2}$ での反射光ベクトルを $C$ とし, 点 $P_{1}$, 点 $P_{2}$ における反射面の法線ベクトルを光 れ光れ $N_{1} ， N_{2}$ とすると，これらの成分は次式のように 表される。

$$
\begin{aligned}
& \boldsymbol{A}=(-\sin \theta,-\cos \theta) \\
& \boldsymbol{B}=\left(x_{2}-x_{1}, z_{2}-z_{1}\right) \\
& \boldsymbol{C}=\left(-x_{2},-z_{2}\right) \\
& \boldsymbol{N}_{1}=\left(-f_{1}^{\prime}\left(x_{1}\right), 1\right) \\
& \boldsymbol{N}_{2}=\left(f_{2}^{\prime}\left(x_{2}\right),-1\right)
\end{aligned}
$$

ここで, $f_{1}^{\prime}\left(x_{1}\right)$ は $f_{1}(x)$ の $x=x_{1}$ における 1 階の導関数， $f_{2}^{\prime}\left(x_{2}\right)$ は $f_{2}(x)$ の $x=x_{2}$ における 1 階の導関数である. これらのべクトルには反射の法則により以下の関係が成り 立つ。

$$
\begin{aligned}
& \left(A+\frac{B}{|B|}\right) \cdot N_{1}=0 \\
& \left(\frac{B}{|B|}+\frac{C}{|C|}\right) \cdot N_{2}=0
\end{aligned}
$$

式 (6), (7) と条件 1,2 より, $f_{1}^{\prime}\left(x_{1}\right)$ は $\left(x_{1}, z_{1}\right)$ の関数に より表されるので, この式を $M_{1}$ から数值積分することに より主鏡の断面形状 $f_{1}(x)$ を求めることができる .この詳 細については, 文献 6) を参照されたい .

3.2 搭載位置の検証 USERS では, 全方位モニタカメ ラ 2 台により冗長構成をとるので, 各全方位モニタカメラ は, 弚れ光れ同時にパドル，CPDR，REMすべてをモニタ できる位置に搭載されなければならない, 弚れゆえ, 第 6 図 に示すように,垂直視野角が 50 度 ( $\theta=90 \pm 25$ 度), ODV1 がSEM 上の REM が結合されている面に，ODV2 が光の 側面に搭載されることになった . 各全方位モニタカメラの取 り付け位置, 角度が異なるのは, ODV1では REM ・SEM

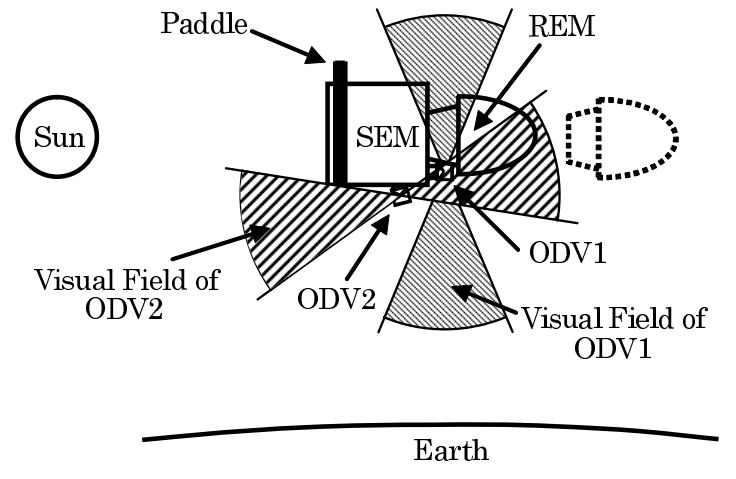

第6图 全方位モニタカメラの搭載位置と視野

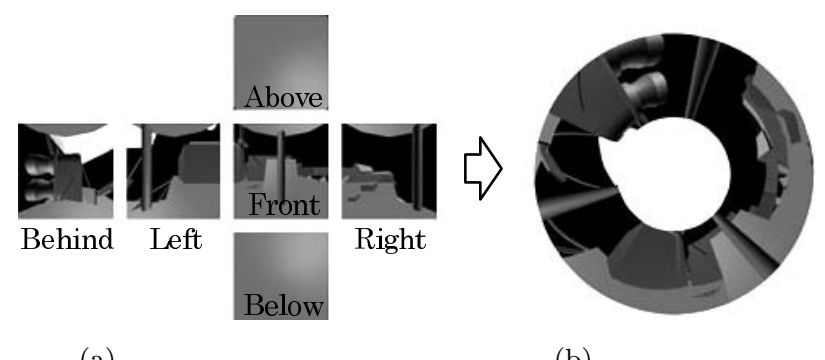

(a) キューフ環境マップ

(b) 模擬撮像画像

第7图 模擬撮像画像の生成

結合部が，ODV2 では分離後に離れ行く REM か映るよう にするためである .

全方位モニタカメラがこれら構造物すべてをモニタでき ることを確認するために，全方位モニタカメラの撮像画像を 模擬作成するためのソフトウェアを開発した .まず, 第 7 图 に示すように，CGソフトにより USERS の CAD データ から全方位モニタカメラを視点とするキューフ環境マップ を生成する .キューフ環境マップとは, 全方位モニタカメラ の周囲のシーンを全方位モニタカメラが立方体の中心にあ るかのように表現した場合の，立方体内側各面に貼られる テクスチャ画像の集合であり, 水平・垂直視野角が 90 度で, 上下左右前後方向の 6 枚の画像からなる.続いて, 我々が 開発したソフトウェアにより，このキューフ環境マップか ら全方位モニタカメラの模擬撮像画像を生成する.第 8 図， 第 9 図にODV1 および ODV2 の模擬撮像画像を示す . れらの画像から，各全方位モニタカメラで構造物すべてを モニタできることを確認した .

3.3 設計「条件 1$\lrcorner$ の入射光の入射範囲を $\theta=65$ 〜 115 度，反射光の入射範囲を $\phi=2.759 \sim 7$ 度，射影を超 広角光学系で最も採用されている等距離射影 (光線の入射 する角度 $\theta$ と画面中央からの距離力比例する射影) と設定 した .「条件 2$\lrcorner$ 副鏡断面形状を，

$$
\left(\frac{x-p}{a}\right)^{2}+\left(\frac{z-q}{b}\right)^{2}=1
$$

で表される楕円の一部とし，この形状は扁平率 $r_{\text {flat }}$ $(=(a-b) / a)$ が与えられることで, 主鏡の内 , 外周上の点 $M_{1,2}$ と副鏡の内外周上の点 $S_{1,2}$ の位置から一意に決まる . 


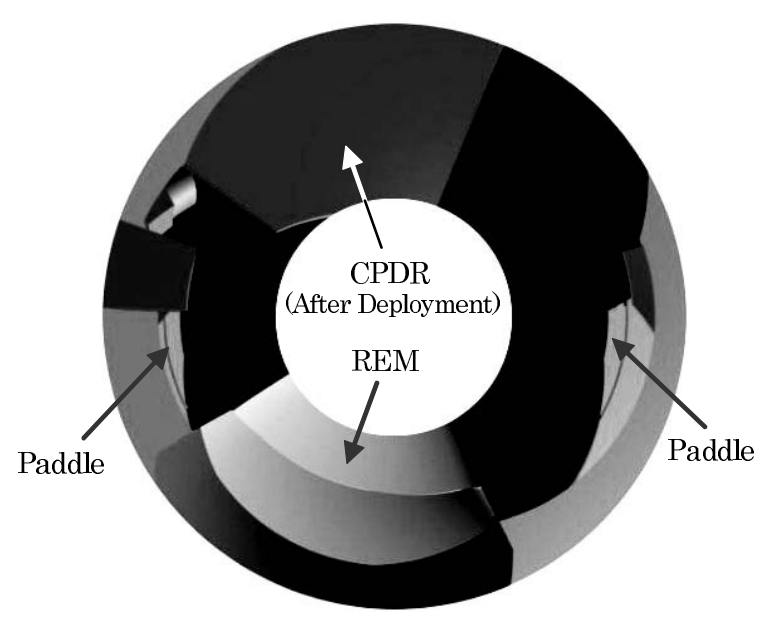

第 8 図 ODV1 の模擬撮像画像

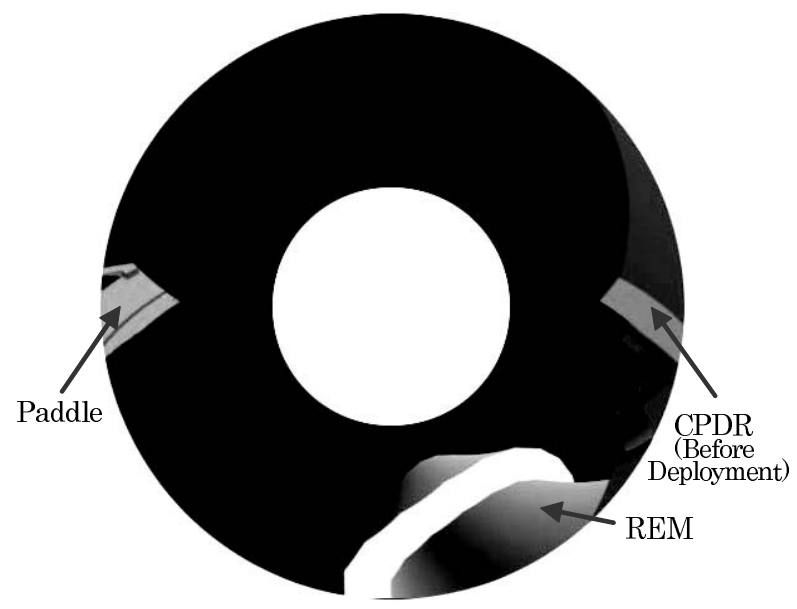

第 9 図 ODV2 の模擬撮像画像 よって,$\left\{r_{\text {flat }}, M_{1,2}, S_{1,2}\right\}$ のパラメータスタディーにより 非点隔差 (像面の $z$ 軸方向の厚み) が最も小さくなるよう に最適設計を行った .

最適設計の結果 , $h=0.525, M_{1}=(7.799,28.629), M_{2}$ $=(39.979,3.725), S_{1}=(2.948,61.131), S_{2}=(7.576$, 61.704) (単位はすべて $\mathrm{mm}$ ) と設定したとき, 非点較差が 2.133(78.302-76.169) mm と最も小さく，つまり，像面 が最も平坦になった . 第 10 図に設計結果を示す.

3.4 光学系の評価 前節で示した設計結果において $1 / 3$ インチ CCD を使うとすると，視点から見た副鏡の見込み 角が約 14 度となるので, 垂直画角約 15.7 度が得られる焦 点距離 $f=12 \mathrm{~mm}$ のレンズを使うこととした .このレン ズを用いた場合の画像の評価を行う.この設計結果から求 められた像面がこのレンズの被写界深度に含まれるならば， 全面で焦点の合った鮮明な画像が得られる．被写界深度の 近点 $P_{\text {near }}$, 遠点 $P_{\text {far }}$ は以下の式で求められる.

$$
\begin{aligned}
& P_{\text {near }}=\frac{f^{2} s}{f^{2}+c F(s-f)} \\
& P_{\text {far }}=\frac{f^{2} s}{f^{2}-c F(s-f)}
\end{aligned}
$$

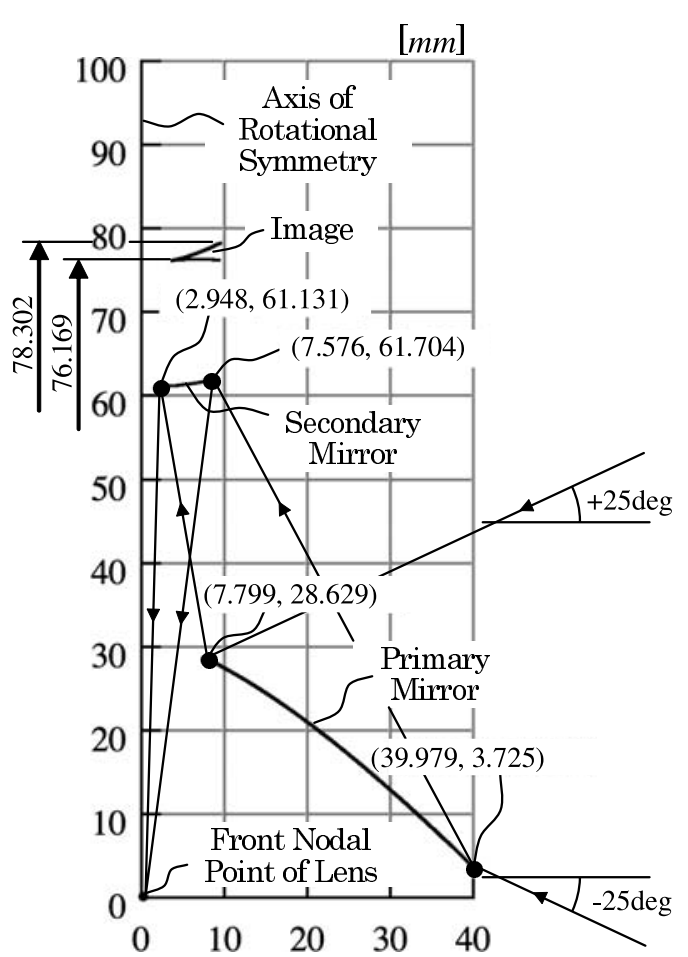

第 10 图 全方位モニタカメラの断面形状

\section{第 1 表 全方位モニタカメラの仕樣}

\begin{tabular}{lc}
\hline 水平画角 & 全周 360 度 \\
垂直画角 & 50 度 ( $\theta=90 \pm 25$ 度 $)$ \\
撮像素子 & $1 / 3$ インチカラー CCD \\
画素数 & 33 万画素 \\
露光 & 自動及びマニュアル, AGC 付き \\
絞り & $F 4.2$ 固定 \\
シャッタースピード & $1 / 30 \sim 1 / 10000$ \\
外形 & $\mathrm{W} 170 \times \mathrm{H} 180 \times \mathrm{D} 170 \mathrm{~mm}$ \\
質量 & $1.7 \mathrm{~kg}$ \\
\hline
\end{tabular}

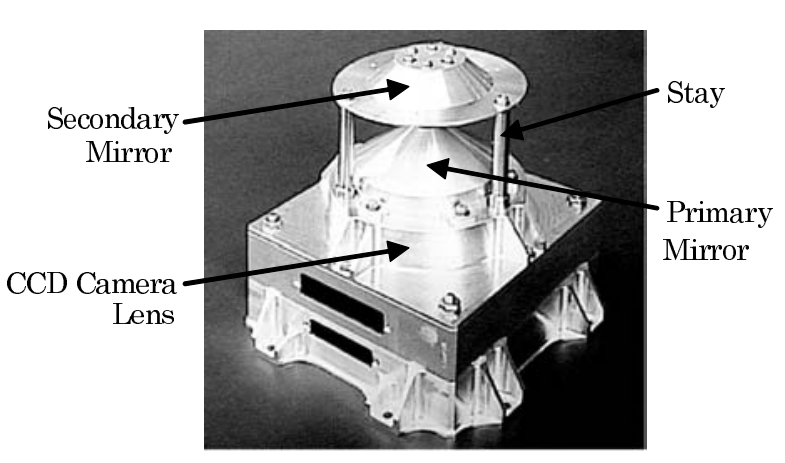

第 11 図 全方位モニタカメラの外観

ここで， $f$ はレンズの焦点距離， $s$ は焦点をあわせた距 離 , $c$ は許容錯乱円径, $F$ は絞り值である $f f$ を $12 \mathrm{~mm}$, $s$ を $77.236 \mathrm{~mm}, c$ を $1 / 3$ インチ CCD の画素サイズであ る $7.4 \mu \mathrm{m}$ として被写界深度を計算すると， $F=4.2$ の場合， $(9)$ 式 , $(10)$ 式より $\left(P_{\text {near }}, P_{\text {far }}\right)=(76.164,78.339) \mathrm{mm}$ と求められ，(76.169〜 78.302) $\mathrm{mm}$ に存在する像面はすべ て被写界深度 $(76.164 〜 78.339) \mathrm{mm}$ 内に含まれる . 絞るほ ど被写界深度は深く (広く) なるので， $F>4.2$ のとき得 


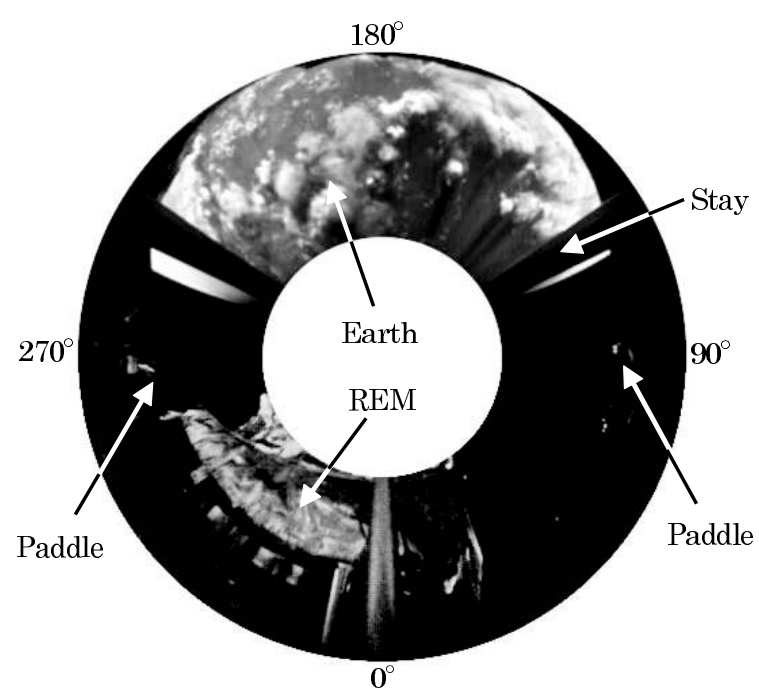

第12図 ODV1 の撮像画像

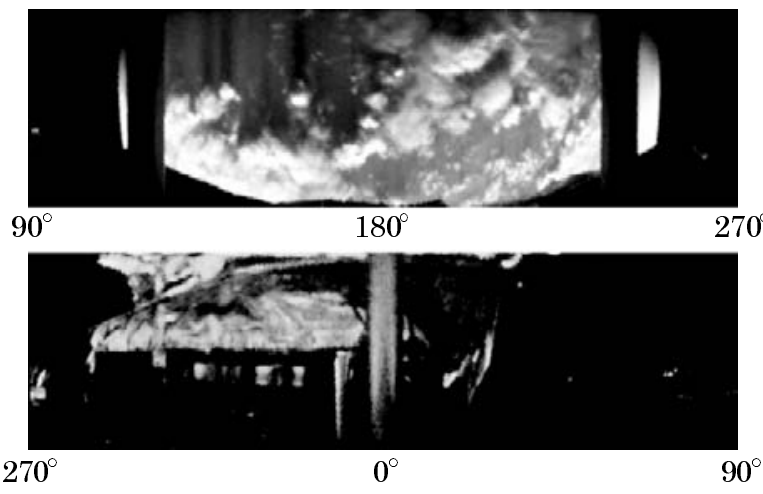

第13図 ODV1 の補正画像

られる全方位画像は全面で焦点のあった鮮明な画像となる ことがわかる.よって，絞りを $F=4.2$ と設定することと した。

3.5 製作 製作した全方位モニタカメラの仕樣を第 1 表 に，外観を第 11 図に示す．2 枚のミラーは超精密旋盤によ り製作したアルミの削り出しで，反射面の酸化防止や保護 のため $\mathrm{MgF}_{2}$ コーティングされている. CCD とレンズに は，反射鏡などの金属にカバーされて直接宇宙線にさらさ れることはないので，防犯カメラ用に市販されている民生 品を放射線試験や熱試験等を経た上で使用した。また，副 鏡の支持には，従来，透明なプラスチックカバーを用いて いたが，打ち上げ時の振動等を考慮し，3 本のチタン製の ステイを用いることとし，反射防止のために表面をつや消 し仕上げとしている．ステイは視野の一部を遮るが , パド ル，CPDR，REM を遮らない位置に配置されている。

\section{4. 軌道上での撮像結果}

衛星搭載全方位モニタカメラは, 衛星の運用が終了した 2005 年 2 月 25 日までの約 2 年半, 宇宙線による画素の損 傷などのトラブルもなく，すべてのミッションを終えること ができた . 撮像例を第 12 16 図に示す. 第 12 図は ODV1

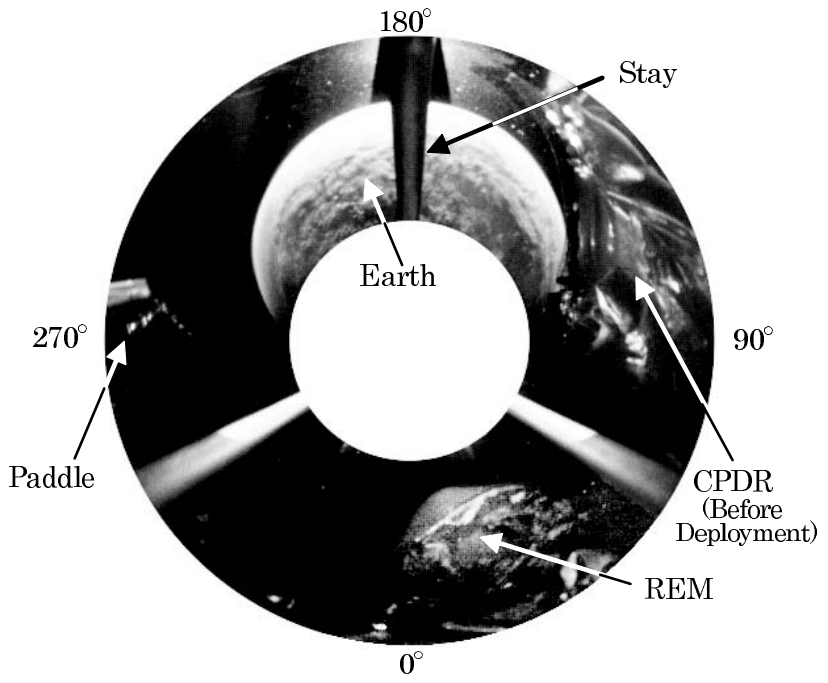

第14図 ODV2 の撮像画像

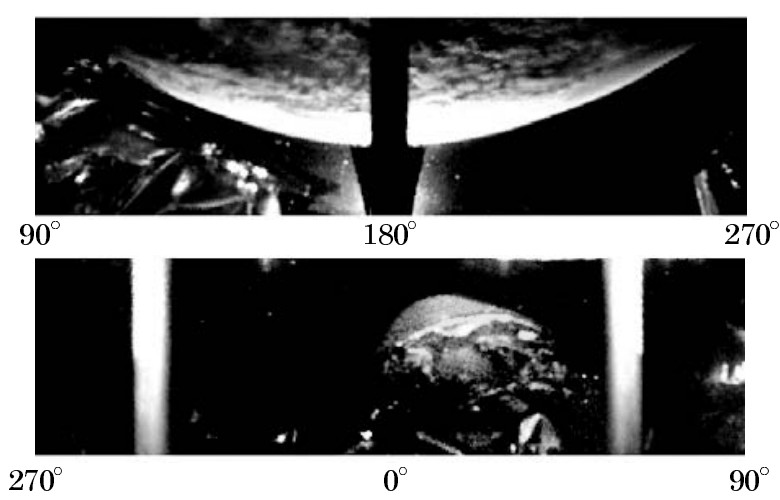

第15図 ODV2 の補正画像

の撮像画像である .撮像画像は中心から外周に向かって仰角 が大きくなる円環状画像で表示されるので，歪が大きく目 視による被写体の認識が難しい.我々は，この円環画像の視 認性を向上させるため，円筒面に投影することで歪の少な いパノラマ画像に補正するためのソフトも開発した . 第 13 図にこのソフトによる第 12 図の補正画像を示す . この画像 からは，展開したパドルや分離前の REM を比較的容易に 確認することができる.第 14 図，第 15 図には ODV2 の撮 像画像および補正画像を示す .この図からも，展開してい るパドルや CPDR, 分離前の REM が確認できる.また , 第 16 図は, REM 分離後に ODV2 により撮影された補正 画像を時系列に並べたものであり，これら図から REM 分 離を確認することができる .

\section{5. ま と め}

我々は衛星搭載全方位モニタカメラを開発した．この全 方位モニタカメラは, 2 枚の回転対称の反射鏡, $\mathrm{CCD}$ カメ ラ , レンズから構成されている. 常に周囲 360 度のパノラ マ画像を得ることができるので, 複数の展開構造物を同時 にモニタすることが可能である．今回 , 全周 360 度 $\times$ 垂直 50 度の視野角を持つ USERS 用の全方位モニタカメラを設 

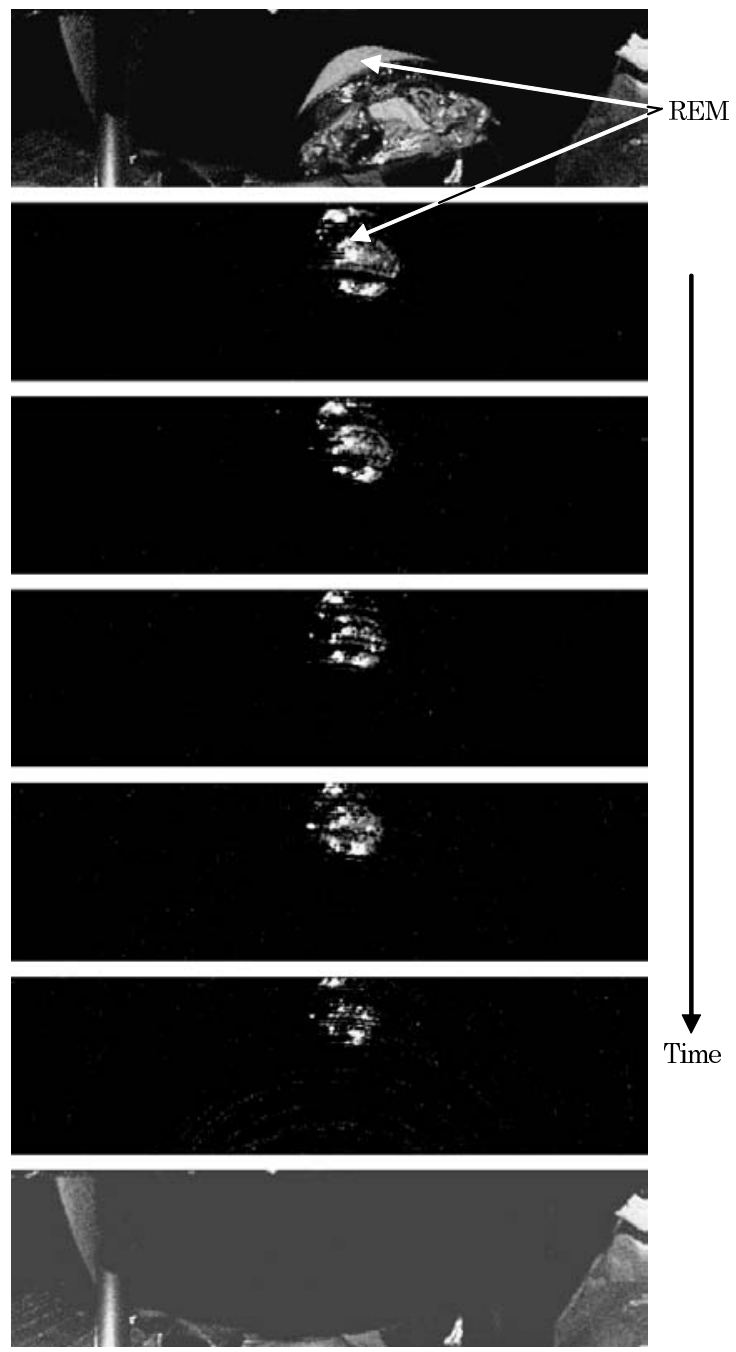

第16 図 ODV2 の補正画像 (REM 分離)
計し，光学系の評価結果からは鮮明な画像が得られること を確認した．また，全方位モニタカメラは冗長系を構成す

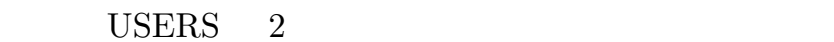
搭載位置からパドル，CPDR，REMすべてがモニタでき ることをシミュレーション検証により確認した .これらの 全方位モニタカメラが搭載された USERS は 2002 年 9 月 10 日に打ち上げられた . ミッション終了となる 2005 年 2 月 25 日までの間, 全方位モニタカメラはトラブルを起こ すことなく軌道上で機能し続け, パドルやラジエタの展開， REM の分離のモニタに利用されることで, すべての目的 を達成した。

$$
\text { 参 考 文 献 }
$$

1) Yagi, Y. and Kawato, S.: Panorama Scene Analysis with Conic Projection, IEEE International Workshop on Intelligent Robots and Systems IROS '90, 1990, pp. 181-187.

2) Hong, J., Tan, X., Pinette, B., Weiss, R. and Reisman, E. M.: Image-Based Homing, Proc. of the 1991 IEEE International Conference on Robotics and Automation, 1991, pp. 620-625.

3) Yamazawa, K., Yagi, Y. and Yachida, M.: Omnidirectional Imaging with Hyperboloidal Projection, Proc. of the IEEE/RSJ Conf. on Intelligent Robotics and Systems, Yokohama, 1993, pp. 1029-1034.

4) Nayar, S. K.: Catadioptrico Omnidirectional Camera, IEEE Conf. on Computer Vision and Pattern Recognition, 1997, pp. $482-488$.

5) Ishiguro, H.: Development of Low-Cost Omnidirectional Vision Sensors and Their Applications, Int. Conf. Information Systems, Analysis and Synthesis, 1998, pp. 433-439.

6) Takeya, A., Kuroda, T., Nishiguchi, K. and Ichikawa, A.: Omnidirectional Vision System Using Two Reflecting Mirrors, Proc. SPIE, Vol. 3430, San Diego, California, 1998, pp. $50-60$.

7) Ijichi, K. and Kanai, H.: Unmanned Space Experiment Recovery System (USERS), Proceedings of 24th International Symposium on Space Technology and Science, Miyazaki, Japan, 2002, pp. $732-736$. 